\title{
AN ANALYSIS ON THE STUDENTS' ERROR IN WRITING REPORT TEXT AT EIGHT GRADE STUDENTS OF SMP N 6 TIMANG GAJAH
}

\author{
Muhammad Hasyimsyah Batubara ${ }^{1}$, Cut Dara Ilfa Rahila ${ }^{2}$, Putri Rahmadani ${ }^{3}$ \\ ${ }^{123}$ IAIN Takengon, Aceh Tengah, Aceh, Indonesia \\ Email: muhammad.hasyimsyahbatubara@gmail.com ${ }^{1,3}$,dara.rahila@gmail.com²
}

\begin{abstract}
This research aims to determine the students' errors in writing report text at eight grade SMP N 3 Timang Gajah students. The research was conduct using a qualitative approach with a descriptive design. The primary data source is the eighth-grade students and the teacher English at SMP N 3 Timang Gajah. The data collection instrument uses observation sheets, interview sheets, and the documentary (test) study and the researcher's data analysis using Miles and Huberman models, including data reduction, display, and verification. The percentage of grade VIII students' achievement in writing report text in the reference made is low, namely only reaching: general nouns $22.04 \%$, at present tense $22.57 \%$, on linking verbs $29.17 \%$ and action verbs are $26.21 \%$. In conclusion, the students still error in writing report text at grade VIII students of SMP N 3 Timang Gajah. Therefore, they should have great motivation and interest in learning report text and get used to practicing it in everyday life.
\end{abstract}

Keywords: Students' Error, Report Text

\begin{abstract}
Abstrak: Penelitian ini bertujuan untuk mengetahui kesalahan yang dilakukan dalam menulis teks report pada siswa kelas VIII SMP N 3 Timang Gajah. Penelitian dilakukan dengan menggunakan pendekatan kualitatif dengan desain deskriptif. Sumber data primer adalah siswa kelas delapan dan guru bahasa Inggris di SMP N 3 Timang Gajah. Instrumen pengumpulan data menggunakan lembar observasi, lembar wawancara, dan studi dokumenter, selanjutnya pada analisis data peneliti menggunakan model Miles dan Huberman, meliputi reduksi data, penyajian, dan verifikasi. Persentasi pencapaian siswa kelas VIII dalam menulis teks laporan dalam acuan yang dibuat sangat rendah yaitu hanya mencapai seperti dalam kata benda umum $22,04 \%$, pada present tense $22,57 \%$, pada verba linking $29,17 \%$ dan kata kerja tindakan adalah 26.21\%. Kesimpulannya, siswa kelas VIII SMP N 3 Timang Gajah masih mengalami kesalahan dalam menulis teks laporan. Oleh karena itu, mereka harus memiliki motivasi dan minat yang besar untuk mempelajari teks report dan membiasakan diri mempraktikkannya dalam kehidupan sehari-hari.
\end{abstract}

Kata Kunci: Kesalahan Siswa, Teks Laporan

\section{INTRODUCTION}

Currently, English is one of the subjects most encouraged to master by students. The demand for mastery of the English language is based on it by people in many countries, including Indonesia. English is transformed as the most comfortable medium of instruction to communicate with each other in life, such as business, economy, technology, education, and social life. According to Keller (2013); Porsch and Köller (2010), in Fleckensteina et al. (2020) convey English is the lingua franca of association of higher education, business, and science in the modern and globalized world. So English is a mandatory qualification for any individual who wants to achieve success in life, as mentioned earlier. Thus, students demand better receptive and productive English competencies to succeed in tertiary education and facilitate decent work in a globalized world (Fleckenstein et al., 2016); Fleckenstein et al., 2020). Master English is not easy, and there are many obstacles faced in learning this language, one of the hardships students often experience is when they have to write in English. 
In junior high school, writing skills are the most necessary skills for developing student competency. Writing lessons are challenging to learn, specifically for junior high school students. However, writing will be easy to understand and will increase if students are diligent in studying. Among the four English skills, writing is considered one of the most troublesome language skills to acquire and teach (Klimova, 2014). In the future, writing ability will develop the best association with reading, listening, and speaking activities (Douglas, 2001). Hidi and Boscolo, 2006; Graham, 2018 mention that writing is a very complex activity, which assigns authors to engage in cognitive, metacognitive, and affective skills simultaneously while also covering social and contextual factors such as environment and social interactions.

Another explanation, writing is a multi-ingredient that prosecutes an understanding of genre-specific requirements, mechanics, objectives, audience, organization, sufficient meta-knowledge, sociocultural background knowledge, as well as the generation of fluent language and lore of the subject matter (Falk, 1979; Taylor, 1981; Perkins and Brutten, 1990; Alexander, Schallert, and Hare, 1991; Wong, 1999; McCutchen, 2000; Chenoweth and Hayes, 2001; Celce-Murcia, 2001; Cumming, 2001; Hyland, 2007; Deane et al., 2008; Kobayashi and Rinnert, 2012; Stapa and Majid, 2017; Hyland, 2019). More profound, as for the linguistic capacity of writing, a writer requires to master spelling, lexis, syntax, punctuation, and phrase choice (National Writing Project and Nagin, 2006 in Karaca and Uysal, 2021). Based on the definition, the mean of it is one form of expertise, especially for students in the junior high school learning process. To write well and correctly, the students must understand the content in the text. If students do not understand the writing, it can indicate that they are not skilled in writing.

Analyzing students' writing text skills is very important because it can help English teachers determine students' abilities. Many students got low scores in writing. Students thought that writing is not exciting and not essential to learn. The teacher must tell students that writing is critical to learn and to write. Some steps must go through for students to succeed in learning to write. Harmer (2004) stated that a teacher must consider at least three steps in teaching writing, (1) The instructor must understand the students' reasons for writing, (2) Instructor should furnish many opportunities for students to write, (3) The instructor should provide valuable and meaningful feedback.

Moreover, there are four distinct phases of the writing process that should be students mastering, which are prewriting, writing, editing, and revising (Haynes, 2010). Like a text report, which has a writing procedure that can make the reader feel easy to understand its meaning. Report text is another type of text in English material created to announce the results of an investigation or announce something that has happened. When the writer saw the SMP N 3 Timang Gajah phenomenon, many students still do not master English writing, and students cannot write English especially report text. Therefore, teachers should find a solution to fix it. Felt-through report text will significantly help students when writing. Students' ability in English lessons needs to be developed by teachers in the classroom. The researcher is interested in researching the students' error in writing report text at SMP N 3 Timang Gajah from the first observation from the explanation above. This research's benefits are that teachers can deepen the 
approach in writing learning by reporting text and development materials to improve the quality of learning English and motivate students to improve writing ability in English, mainly on report text material.

\section{LITERATURE REVIEW}

\section{The Nature of Writing}

Writing plays an essential part in our life. Not only teachers but also students can express and show information in written language. It is disciplinary, which means interpreting persuasive writing and how knowledge should be communicated amongst disciplinary members (Hyland, 2003). Additional, the writing purpose of building the character of a writer in scientific disciplines, facilitates the preservation of disciplinary norms and values within genres, and assist society to develop and conceive of how meaning is negotiated among writers and readers (Par'e, 2014; Mitchell, 2018; in Kim M. Mitchell, 2021). Theoretically, writing is the process of discovering and a transaction with the word, whereby presently thinks, idea, feels, and perceive on paper or other media (Meyers, 2005). It is a skill as an activity that is important to be developed in any language.

Moreover, writing is a way to keep thinking of something that is in mind. Writing needs to be done by students and invited by the teacher. Like that, writing is a communication system between writers and readers who do not meet (Bryne,1991). Furthermore, writing is the action of composing ideas in a sentence, and the ideas have to be well organized so that they will be meaningful to the readers. According to Nunan (2003); Creme and Lea (2003) elucidate writing is a thought process about finding ideas, thinking, and putting them in words in good writing or arranging those ideas in good formation so that they become clear statements and paragraphs. According to statements, writing is the activity of putting the contents of the mind in skillfully. By writing skills make people understand quickly the contents of messages contained in the text. Indeed, writing can also be defined as a process of production text. However, in writing a process, people must pay concern to some writing stages: planning, drafting, editing (revising), and the final product (Hayes and Flower, 1980; Flower and Hayes, 1981; Richard, 2002; Oshima and Hogue, 2007; Johnson, 2008; Mitchell et al., 2017; Mitchell et al., 2017). Hyland states that illustrator writing stages give students a clear concept that writing is pivotal to producing good writing (Hyland, 2004). Furthermore, writing activities not only focus on the final result but also pay attention to getting used to practicing it as often as possible.

\section{Report Text}

A reported text is a script that purposes to portray as it is, with reference to various natural, human-made, and social phenomena in our environment (Gerrot and Wignell, 1994). The report text is a study of the result of an observation about the place, animal, things, or person. On the other hand, it tells about the factual text that describes the way things are, concerning the whole range of phenomena, natural, syntactic, and social, in our environment (Literacy and Education Network, 1991). A report is a form of 
composition or discourse trying to present an event or occurrence. It should tell about the factual text that events are arranged in some valuable ways. It describes something based on systematic observation and analysis. Therefore, a report text is a text that is constructed to retell an event that happened.

\section{RESEARCH METHODOLOGY}

In this study, the writer uses qualitative descriptive, and this study was carried out by formulating the problem, collecting the data, classifying, and explaining the result. Qualitative research is naturalistic research, and it is the research that getting the database on the description of the situation (Suharsimi, 2006). Qualitative descriptive is research intended to investigate the situation, conditions, or the other things mentioned, and the result is present in the form of a research report (Suharsimi, 2006). In this study, the research design using a descriptive method using observation techniques aimed at all subjects of the research by providing an observation sheet that each participant must fill. Then, using the interview to know the errors students often encounter in the lesson, and the last, using the test to find out the data from the students' error in writing report text at SMP N 3 Timang Gajah. The primary source is the source that can give valuable information directly (Sugiyono, 2008). Based on the definition, the primary source is to give prominent data related to the research problems. In this study, a primary source is the 16 students SMP N 3 Timang Gajah class VIII. The technique of collecting data such as observation, interview, and test based on purpose. Based on the explanation above, data will be taken from the informant in error in writing report text at SMP N 3 Timang Gajah. After collecting the data, the writer analyzes the data. According to Miles and Huberman, there are three steps to analyze data: data reduction, data display, and data verification (Miles and Huberman, 1994).

\section{FINDINGS AND DISCUSSION}

\section{The Result of Observation}

Based on the observation that had been in this research, the researcher concludes, the students' error in writing report text can be seen in the table below:

Table 1. Students observation sheet

\begin{tabular}{clll}
\hline No & \multicolumn{1}{c}{ Indicators } & \multicolumn{2}{c}{ Categories } \\
\cline { 3 - 4 } & & Yes & No \\
\hline 1. & The students are enthusiastic about learning report text & $\checkmark$ & \\
\hline 2. & The students using passive voice & $\checkmark$ & \\
\hline 3. & The students understanding of the material & $\checkmark$ & $\checkmark$ \\
\hline 4. & The students ask a teacher about the report text material & $\checkmark$ \\
\hline 5. & Students can be using vocabulary in writing the sentence & \\
\hline 6. & The students like report text & $\checkmark$ & \\
\hline 7. & The students using a dictionary on English lesson & $\checkmark$ \\
\hline 8. & The students use grammatical rule & $\checkmark$ \\
\hline
\end{tabular}


9. The students still feel difficulty translating a sentence

10. The students have been confused about learning report text

In the observation, the researchers concluded that second-grade SMP N 3 Timang Gajah still have the error in the writing report text.

\section{The Result of the Interview}

\section{The teacher's interview}

Furthermore, based on the interview that had been done during the research, the teacher of SMP N 3 Timang Gajah states, there are some errors faced by the students SMP N 3 Timang Gajah in writing report text, there are:

1. The students low in arranging the text because they have enough vocabulary.

2. The source of learning that is used is still limited, and the students feel difficult to find out information about the text.

3. The students felt it challenging to write because the language used should be in English, which means the students' background in mastering English still low. Despite the unable to write report text clearly and easily.

4. The student's ability to make a relevant type of text is low.

5. The students' motivation was the main problem in teaching writing.

\section{The students' interview}

The researcher also gave an interview for the students in the VIII grade. The result of this interview was that students felt difficulty in arranging the sentences on report text because of limited vocabulary and sourcebook from the teacher in learning.

\section{The Result of Documentation}

After finding out the student's errors in writing report text by implementing observation and interview in this research, the researcher continues the research on finding out the students' writing ability by using the test on the documentary study. There were some topics that the researcher gave to the students in writing tests, like is "The Flag". The tets consist of analysis about the writing report text from General Noun (GN), Present Tense (PT), Linking Verbs (LV), and Action Verbs (AB). To know the students' errors, the researcher used the following standard:

Table 2. The standard score

\begin{tabular}{lc}
\hline Explanation & Score \\
\hline General noun $(\mathrm{GN})$ & 25 \\
\hline Present tense (PT), & 25 \\
\hline Linking verbs (LV) & 25 \\
\hline Action verbs (AB) & 25 \\
\hline
\end{tabular}

Based on the test result in this research, the eighth-grade students at SMP N 3 Timang Gajah still have limitations or errors in writing report text, where the students score still in category low. The data in the following table. 
Jurnal As-Salam Vol. 5 No. 1 Januari - Juni 2021: 10 - 19

Muhammad Hasyimsyah Batubara, Cut Dara Ilfa Rahila, Putri Rahmadani

Table 3. The recapitulation of the students' errors in writing recount text

\begin{tabular}{|c|c|c|c|c|c|c|}
\hline \multirow[t]{2}{*}{ No } & \multirow[t]{2}{*}{ Name } & \multicolumn{4}{|c|}{ Error Classification } & \multirow[t]{2}{*}{ Total of Errors } \\
\hline & & GN & PT & $\mathbf{L V}$ & $\mathbf{A V}$ & \\
\hline 1 & Alhadi Munara & 7 & 10 & 12 & 14 & 43 \\
\hline 2 & EkaSyah Putra & 10 & 7 & 13 & 9 & 39 \\
\hline 3 & Haryandi Rahmad & 8 & 8 & 9 & 8 & 33 \\
\hline 4 & Hendri Gunawan & 8 & 8 & 10 & 7 & 33 \\
\hline 5 & Heriyansyah Putra & 7 & 8 & 12 & 8 & 35 \\
\hline 6 & Indri Dwi Ultary & 7 & 8 & 10 & 9 & 34 \\
\hline 7 & Irfan Arami & 9 & 7 & 9 & 7 & 32 \\
\hline 8 & Khairi Dinar & 7 & 8 & 8 & 10 & 33 \\
\hline 9 & Lasrikaina & 8 & 7 & 9 & 12 & 36 \\
\hline 10 & Magfirah Wahyu & 8 & 8 & 12 & 9 & 37 \\
\hline 11 & Malik Asipa & 7 & 7 & 10 & 7 & 31 \\
\hline 12 & Maulida Sari & 9 & 9 & 9 & 8 & 35 \\
\hline 13 & Rizka Randa & 8 & 10 & 8 & 8 & 34 \\
\hline 14 & Safina & 7 & 8 & 12 & 8 & 35 \\
\hline 15 & Tharmizan Dharma & 7 & 9 & 10 & 12 & 38 \\
\hline 16 & Zainal Abidin & 10 & 8 & 15 & 15 & 48 \\
\hline & Total & 127 & 130 & 168 & 151 & 576 \\
\hline & Percent & $22,04 \%$ & $22,57 \%$ & $29,17 \%$ & $26,21 \%$ & $99,99 \%$ \\
\hline
\end{tabular}

The researcher had found the data from the students in a general noun (GN), present tense (PT), linking verbs (LV), and action verbs (AB). The students in the eighth grade of SMP N 3 Timang Gajah wrote report text at the flag. In analyzing the students' writing, the highest error score is getting students initially ZA who got 48, and the lowest score is MA in 31. The error score in 43 is AM. Next, the error in 39 is EF, and the score of 38 is TD. The student in score 37 is MW, and in 36 is L. There are three students in 35 errors score, such as HP, MS, and S. Then, the students with errors score 34 are IDU and RR. Next, in the 33 errors score, they are HR, HG, and KD. Besides, other students get the errors at 32 is IA.

The test in the VIII grade can be seen that the total students' errors were 576, errors of the general noun $(\mathrm{GN})$ is 127 , present tense (PT) was 130, linking verbs (LV) was 168 , and action verbs $(\mathrm{AB})$ is 151 . It can be concluded that the errors on writing in report text at eighth grade with a total error such as an error in a general noun (GN) are 127 $(22,04 \%)$, present tense (PT) was 130 (22,57\%), linking verbs (LV) was $168(29,17 \%)$, and action verbs $(\mathrm{AB})$ is $151(26,21 \%)$. This data shows the low average achievement of students in writing the report text. It is proved that the student's performance is not following the reference score made, which is 25 (100\%) of each reference standard. In conclusion, this finding, especially from the test result, may conclude that writing report 
text's ability was still low. The students at the second grade SMP N 3 Timang Gajah faced an error in the writing report text.

\section{Discussion}

At this point, the researcher discusses the research finding and analyzing the previous point's data. The researchers made two main aspects of this discussion, are:

\section{The student's errors in the writing report text}

Lean back the technique of data collection, and the researcher can find out that:

a. Students' errors in arranging the sentences caused the limitation in vocabulary because the students must be mastering the vocabulary to made the influence the product of writing they made in the report text.

b. The students were challenging to write because they had limited background knowledge.

c. The students' understanding of report text, but low in constructing it.

d. The students felt difficulty writing because they had a poor understanding of the language they used.

e. The last is that low motivation becomes the main factor that caused the students' error in writing report text at SMP N 3 Timang Gajah.

\section{The English teacher in the teaching report text}

The researchers find out the English teachers' information in teaching English material, especially on report text. The teacher is given the new sources as material in teaching English on report text. Besides, the teacher low on explaining the material based on the students' ability in the classroom, so most students are less motivated to learn. The last, the teacher rarely to a made evaluation in teaching-learning to give achievement to each student. So, the students still felt using English on writing report text.

The ways used by the English teacher in teaching writing, especially in report text, have various strategies. However, as general ways used were as follows:

a. Introduce the text to the students.

b. Ask the students to read the text and understanding part of the text.

c. Ask the students to ask about the matter that they faced.

d. Ask the students to write the text based on students' experiences.

Based on the information above, it can be concluded that there are many problems that the students still face in writing report text. So, the researcher agrees that the English teacher should use a suitable teaching technique for helping the students.

\section{CONCLUSIONS}

The students' error in writing report text at SMP N 3 Timang Gajah from some aspects they are students errors on arranging the sentences caused by their limitation vocabulary, the students' motivation was the main problem in teaching writing, where according to him there are many relevant sources, but the students do not want to read them. By this result, the students' error in writing report text at SMP N 3 Timang Gajah is a danger. From the conclusion above, some matters must grow teaching quality, especially in students' motivation in writing, and the way the teacher teaches is noticed with the suitable method. 
Jurnal As-Salam Vol. 5 No. 1 Januari - Juni 2021: 10 - 19

Muhammad Hasyimsyah Batubara, Cut Dara Ilfa Rahila, Putri Rahmadani

\section{REFERENCES}

Alexander, P. A., Schallert, D. L., \& Hare, U. C. (1991). Coming to terms: How researchers in learning and literacy talk about knowledge. Review of Educational Research, 61, 315-343. https://doi.org/10.3102\%2F00346543061003315

Bryne, Donn. (1991). Teaching Writing Skill. London: Longman Group Ltd.

Chenoweth, N. A., \& Hayes, J. R. (2001). Fluency in writing generating text in L1 and L2. Written Communication, 18, 80-98. https://doi.org/ 10.1177/0741088301018001004

Celce-Murcia, M. (2001). Teaching English as a Second or Foreign Language (3rd. Ed.). Boston: Heinle \& Heinle.

Creme, P., \& Lea, M. R. (2003). Writing at university (2nd ed.). Maidenhead: Open University Press.

Cumming, A. (2001). The difficulty of standards, for example in L2 writing. In T. Silva, \& P. Matsuda (Eds.). On second language writing (pp. 209-229). Mahwah, NJ: Lawrance Erlbaum Associates.

Deane, P., Nora O., Quinlan, T., Fowles, M., Welsh, C. \& Bivens-Tatum, J. (2008). Cognitive Models of Writing: Writing Proficiency as a Complex Integrated Skill. Princeton, NJ: ETS.

Douglas, H. Brows. (2001). Teaching by Principles and Interaction Approach to Language Pedagogy. California: San Fransisco University.

Falk, J. S. (1979). Language Acquisition and the Teaching and Learning of Writing. College English, 41, 436-447.

Fleckenstein, J., Leucht, M., Pant, H.-A., \& Koller, O. (2016). Proficient beyond borders: Assessing non-native speakers in a native speakers' framework. Large-scale Assessments in Education, 4(19), 1-19. https://doi.org/10.1186/s40536-016-0034-2.

Flower, L., \& Hayes, J. R. (1981). A cognitive process theory of writing. College Composition and Communication, 32(4), 365-387. https://doi.org/10.2307/356600

Gerot, Linda and Wignell, Peter. 1994. Making Sense of Functional Grammar. Sydney: Gerd Stabler.

Graham, S. (2018). A revised writer (s)-within-community model of writing. Educational Psychologist, 53(4), 258-279.

https://doi: 10.1080/00461520.2018.1481406

Harmer, J. (2004). How to teach writing. London: Longman.

Hayes, J., \& Flower, L. (1980). Identifying the organization of writing processes. In L. W. Gregg, \& E. R. Steinberg (Eds.), Cognitive processes in writing (pp. 3-30). Hillsdale, NJ: Lawrence Erlbaum Associates.

Haynes, Judie. (2010). Teaching English Language Learners Across the Content Areas. Virginia: ASCD.

Hidi, S., \& Boscolo, P. (2006). Motivation and writing. In C.A. MacArthur, S. Graham, \& J. Fitzgerald (Eds), Handbook of writing research (pp. 144-157). New York, NY: Guilford Press. https://doi.org/10.1007/s11145-008-9121-2

Hyland, K. (2003). Genre-based pedagogies: A social response to the process. Journal of Second Language Writing, 12(2003), 17-29. https://doi.org/10.1016/S1060-3743 (02)00124-8 
Hyland, K. (2004). Genre and Second Language Writing. Ann Arbor: University of Michigan Press.

Hyland, K. (2007). Genre pedagogy: Language, literacy and L2 writing instruction. Journal of Second Language Writing, 16(3), 148-164. https://doi.org/10.1016/j.jslw.2007.07.005

Hyland, K. (2019). Second language writing (2nd ed.). Cambridge and New York: Cambridge University Press.

Johanna Fleckensteina, Stefan Keller, Maleika Kruger, Richard J. Tannenbaum, Olaf Koller. Linking TOEFL iBT® writing rubrics to CEFR levels: Cut scores and validity evidence from a standard setting study. Assessing Writing 43(2020), 100420. https://doi.org/10.1016/j.asw.2019.100420

Johnson, Andrew P. (2008). Teaching Reading and Writing: A Guidebook for Tutoring and Remediating Students. United States of America: Rowman \& Littlefield Publishers, Inc.

Karaca, Mehmet and Uysal, H. H. (2021). The development and validation of an inventory on English writing teacher beliefs. Assessing Writing, 47(2021), 100507. https://doi.org/10.1016/j.asw.2020.100507.

Keller, S. (2013). Integrative Schreibdidaktik Englisch für die Sekundarstufe. Theorie, Prozessgestaltung, Empirie. Integrative writing instruction in English at secondary level. Theory, process design, empirical evidence. Tubingen: Narr.

Kim M. Mitchell, Diana E. McMillan, Michelle M. Lobchuk, Nathan C. Nickel, Rasheda Rabbani, Johnson Li. Development and validation of the Situated Academic Writing Self-Efficacy Scale (SAWSES). Assessing Writing 48(2021), 100524. https://doi.org/10.1016/j.asw.2021.100524

Klimova, B.F. (2014), Constraints and Difficulties in the Process of Writing Acquisition. Procedia-Social and Behavioral Sciences, 122(2014), 433 - 437.

Kobayashi, H., \& Rinnert, C. (2012). Understanding L2 writing development from a multicompetence perspective: Dynamic repertoires of knowledge and text construction. In R. M. Manchon (Ed.). L2 writing development: Multiple perspectives (pp. 101-134). Berlin: De Gruyter Mouton.

Literacy and Education Network. (1991). A Genre-Based Approach to Teaching Writing. Australia: Common Ground.

Majid, A. H. A. \& Stapa, S. (2017). The Use of Scaffolding Technique via Facebook in Improving Descriptive Writing Among ESL Learners. The Southeast Asian Journal of English Language Studies-Vol. 23(4),77-88. http://doi.org/10.17576/3L-2017-2304-07.

Mayers, A. (2005). Gateways to academic writing effective sentences, paragraphs, and essays. New York: Longman.

McCutchen, D. (2000). Knowledge, processing, and working memory: Implications for a theory of writing. Educational Psychologist, 35(1), 13-23. https://doi.org/10.1207/S15326985EP3501_3

Miles and Huberman. (1994). Qualitative Data Analysis (2nd edition). CA: Sage Publications.

Mitchell, K. M., Harrigan, T., Stefansson, T., \& Setlack, H. (2017). Exploring selfefficacy and anxiety in first-year nursing students enrolled in a discipline-specific scholarly writing course. Quality Advancement in Nursing Education, 3(1), Article 4.

https://doi.org/10.17483/2368-6669.1084 
Mitchell, K. M., Rieger, K. L., \& McMillan, D. E. (2017). A template analysis of writing self-efficacy measures. Journal of Nursing Measurement, 25(2), 205-223. https:// doi.org/10.1891/1061-3749.25.2.205

Mitchell, K. M. (2018). Constructing writing practices in nursing. Journal of Nursing Education, 57(7), 399-407. https://doi.org/10.3928/01484834-20180618-04

National Writing Project, \& Nagin, C. (2006). Because writing matters: Improving student writing in our schools. San Francisco: JosseyBass.

Nunan, D. (2003). Practical English language teaching. Singapore: McGraw-Hill.

Oshima, A., \& Hogue, A. (2007). Introduction to academic writing (4th ed.). New York: Pearson Education Press.

Par'e, A. (2014). Rhetorical genre theory and academic literacy. Journal of Academic Language and Learning, 8(1), A83-A94.

Retrieved from https://journal.aall.org.au/index.php/jall/article/view/313

Perkins, K \& Brutten, S. R. . (1990). Writing: A Holistic Or Atomistic Entity?. Journal of Basic Writing, 9(1), 75-84. https://wac.colostate.edu/docs/jbw/v9n1/perkins.pdf

Porsch, R., \& Koller, O. (2010). Standardbasiertes Testen im Fach Englisch. In W. Bos, E. Klieme, \& O. Koller (Eds.). Standard-based assessment in English. Munster: Waxmann: Schulische Lerngelegenheiten und Kompetenzentwicklung. Festschrift fur Jurgen Baumert.

Richard. (2002). Methodology in Language Teaching: An Anthology of Current Practices. New York: Cambridge University Press.

Sugiyono. (2008). Metode Penelitian Kunatitatif Kualitatif dan R\&D. Bandung: Alfabeta.

Suharsimi, Arikunto. (2006). Prosedur Penelitian Suatu Pendekatan Praktik. Jakarta: Rineka Cipta.

Taylor, B. P. (1981). Content and Written Form: A Two-Way Street. TESOL Quarterly $15,5-13$. https://doi.org/10.2307/3586368

Wong, B. (1999). Metacognition in writing. In R. Gallimore, L.P. Bernheimer, D. L.MacMillan, D. L. Speece, \& S. R. Vaughn (Eds.). Developmental perspectives on children with high-incidence disabilities (pp. 183-198). Mahwah, NJ: Lawrence Erlbaum. 